\title{
BIFLAGELLATE SPERMATOZOON STRUCTURE OF THE HERMAPHRODITE FISH Satanoperca jurupari (HECKEL, 1840) (TELEOSTEI, CICHLIDAE) FROM THE AMAZON RIVER
}

\author{
MATOS, E., ${ }^{1}$ SANTOS, M. N. S. ${ }^{2}$ and AZEVEDO, C. ${ }^{3}$ \\ ${ }^{1}$ Faculdade de Ciências Agrárias do Pará, Av. Tancredo Neves, 2501, CEP 66077-530, Belém, PA, Brazil \\ ${ }^{2}$ Centro de Ciências Biológicas, Universidade Federal do Pará, Belém, PA, Brazil \\ ${ }^{3}$ Department of Cell Biology, Institute of Biomedical Sciences and CIMAR, University of Oporto, Porto, Portugal \\ Correspondence to: Edilson Matos, Faculdade de Ciências Agrárias do Pará, Av. Tancredo Neves, 2501, \\ CEP 66077-530, Belém, PA, Brazil, e-mail: ed.matos@bol.com.br \\ Received October 4, 2001 - Accepted December 18, 2001 - Distributed November 30, 2002
}

(With 11 figures)

\begin{abstract}
The ultrastructural features of the sperm were studied in the hermaphroditic teleost Satanoperca jurupari HECKEL, 1840 from Amazon River. Spermatocytes, spermatids and sperm develop in the testicular cysts among the different oocyte stages. Different stages of early spermatocyte development, mainly the ones with synaptonemal complexes were often observed. The mature spermatozoa belong to the introsperm type, with a short head ( $3 \mu \mathrm{m}$ long and $1.3 \mu \mathrm{m}$ wide) without acrosome, short midpiece $(\sim 1.2 \mu \mathrm{m}$ long and $1.8 \mu \mathrm{m}$ wide) containing several mitochondria surrounding two centrioles and forming a mitochondrial collar. They have two flagella (each $\sim 15 \mu \mathrm{m}$ long) each of which has a common $9+2$ microtubular pattern. Each flagellum has two opposite lateral cytoplasmic extensions that begin about $3 \mu \mathrm{m}$ the midpiece still close to the end piece of flagellum.
\end{abstract}

Key words: hermaphrodite, teleost, Satanoperca jurupari, ultrastructure, sperm.

\section{RESUMO}

\section{Estrutura do espermatozóide biflagelado do peixe hermafrodita, Satanoperca jurupari Heckel, 1840 (Teleosteo, Cichlidae) do rio Amazonas}

Foram estudados aspectos ultra-estruturais do espermatozóide do teleósteo hermafrodita Satanoperca jurupari (HECKEL, 1840) do rio Amazonas. Em diferentes oocistos testiculares encontram-se fases evolutivas de espermatócitos, espermátides e espermatozóides. Nos estádios mais jovens, nos espermatócitos, foram observados os respectivos complexos sinaptonêmicos. O espermatozóide maduro do tipo "introsperm" apresenta cabeça pequena de $\sim 3 \mu \mathrm{m}$ de comprimento e $1,3 \mu \mathrm{m}$ de largura, sem acrosoma, com uma pequena peça intermediária de $\sim 1,2 \mu \mathrm{m}$ de comprimento e $1,8 \mu \mathrm{m}$ de largura, contendo algumas mitocôndrias esféricas, circundando os dois centríolos e formando um colar mitocondrial. Esse espermatozóide apresenta 2 flagelos, cada um com $\sim 15 \mu \mathrm{m}$ de comprimento e com a formação microtubular comum de $9+2$. Cada flagelo tem 2 extensões citoplasmáticas lateralmente opostas, sendo formadas cerca de $3 \mu \mathrm{m}$ abaixo da peça intermediária, acompanhando o flagelo até a parte final.

Palavras-chave: hermafrodita, teleosteo Satanoperca jurupari, ultra-estrutura, espermatozóide. 


\section{INTRODUCTION}

The main events of the spermatogenesis described in different taxonomic groups are quite well documented (see review by Baccetti \& Afzelius, 1976). Among these groups, teleost fishes have spermatozoa that have been classified as being of the introsperm type, although shape and structural variations from aflagellate to biflagellate have caused sperm types to be renamed after their reproductive biology (Rouse \& Jamieson, 1987).

However, the existing literature on spermiogenesis producing sperm with two flagella were only described in few teleost families as Bagridae (Yasuzumy, 1971), Batrachoididae (Hoffman, 1963), Myctophidae (Mattei \& Mattei, 1976), Apogonidae (Mattei \& Mattei, 1984) and Zoarcidae (Yao et al., 1995). On the other hand, the presence of the two lateral cytoplasmic extensions (or ribbons) in opposite insertion on each flagellum has been described in few teleost species (Billard, 1970) as well as in other fish groups (Mattei, 1970; Matos \& Azevedo, 1989). Despite a well and detailed date on spermatogenesis, the majority of teleost spermatozoa remains unexamined lacking data to allow the establishment of phylogenetic relationships amongst the teleost fishes (Mattei, 1991; Gwo et al., 1993).

The present study provides an ultrastructural description of the spermiogenesis and mature spermatozoon of the teleost Satanoperca jurupari that is a simultaneous hermaphrodite species and undergoes internal auto fertilization.

\section{MATERIAL AND METHODS}

Fragments of the ovotestis of the hermaphrodite fish, Satanoperca jurupari Heckel, 1840 (Teleostei, Cichlidae), collected in the estuarine region of the Amazon River near Belém, Brazil, were used for light (LM) and transmission electron microscopical (TEM) studies. For LM study, smears of the ovotestis without fixation or fixed with buffered $2 \%$ glutaraldehyde were observed by Nomarski differential interference-contrast optics (DIC). For TEM, small fragments of ovotestis were fixed for $3 \mathrm{~h}$ in $3 \%$ glutaraldehyde in $0.2 \mathrm{M}$ sodium cacodylate buffer $(\mathrm{pH} 7.2)$ at $4^{\circ} \mathrm{C}$, washed in the same buffer for $2-4 \mathrm{~h}$ at $4^{\circ} \mathrm{C}$, and postfixed in $2 \%$
OsO4 buffered with the same solution for $2 \mathrm{~h}$ at the same temperature. The fragments were dehydrated in a graded ethanol series and embedded in Epon. The semithin sections were stained by methylene blue and observed by LM. Ultrathin sections, cut with a diamond knife and stained with uranyl acetate and lead citrate, were observed in a JEOL 100CXII TEM operated at $60 \mathrm{kV}$.

\section{RESULTS}

The ovotestis lobe of Satanoperca jurupari is composed of a larger number of radially arranged, elongate sac-like follicles. Each follicle contains both developing eggs and sperm. The ovary portions are located in the distal zone of the follicles while the testicular cysts are located in the proximal zone in close contact with the ovotestis lumen (Figs. 1 and 2). Some free mature sperm were found among oocytes and within the lumen of the ovotestis.

The primary spermatocytes are irregular shaped cells (Fig. 3). Their nuclei are spherical, containing the synaptonemal complexes. In the cytoplasm there are a few circular mitochondrias and the other cytoplasmic organelles (Fig. 3).

Near oocytes we observe some spermatids in different phases of maturation (Fig. 4), some of which in close contact with Sertolli cells (Fig. 5). The latter, containing a prominent nucleus, are located at the periphery of the testis cyst (Fig. 5).

The mature spermatozoa consist of a short head containing a nucleus but without acrosome, a midpiece and two tails (Figs. 6 and 11). The electron dense sperm nucleus presents fewer than two forms. Most of the nuclei were cylindrical 3 $\mu \mathrm{m}$ long and $1.3 \mu \mathrm{m}$ wide and with a rounded anterior end (Fig. 6). Some other spermatozoa contain a circular nucleus with 3.0-3.4 $\mu \mathrm{m}$ in diameter. The midpiece consists of a collar ring-shaped mitochondrion containing several mitochondria situated in different levels, and two centrioles (Figs. 6, 8-10).

At the posterior region of the midpiece it recedes inwardly and upwardly, thus forming a curved flange delimitating a cytoplasm collar formed by the mitochondria (Figs. 6, 8-10). This collar is $0.5 \mu \mathrm{m}$ high (Fig. 6). Belonging to this region the plasmalemma of each flagellum develops two lateral cytoplasmic extensions in opposite insertion on the flagellum (Figs. 6 and 7). 

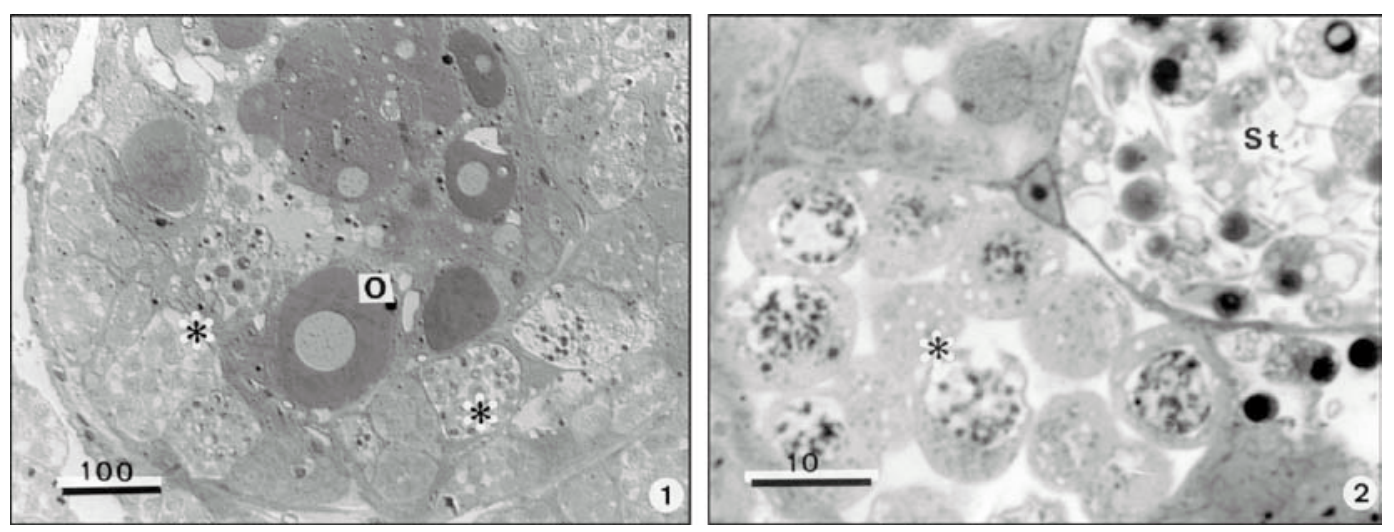

Fig. 1 - Satanoperca jurupari hermaphrodite teleostean fish. Semithin section of the ovotestis showing different stages of the spermatogenesis $\left(^{*}\right)$ surrounding several oocyts $(\mathrm{O})$. Fig. $\mathbf{2}-$ Semithin section of two cysts containing spermatocytes $(*)$ and spermatids $(\mathrm{St})$.
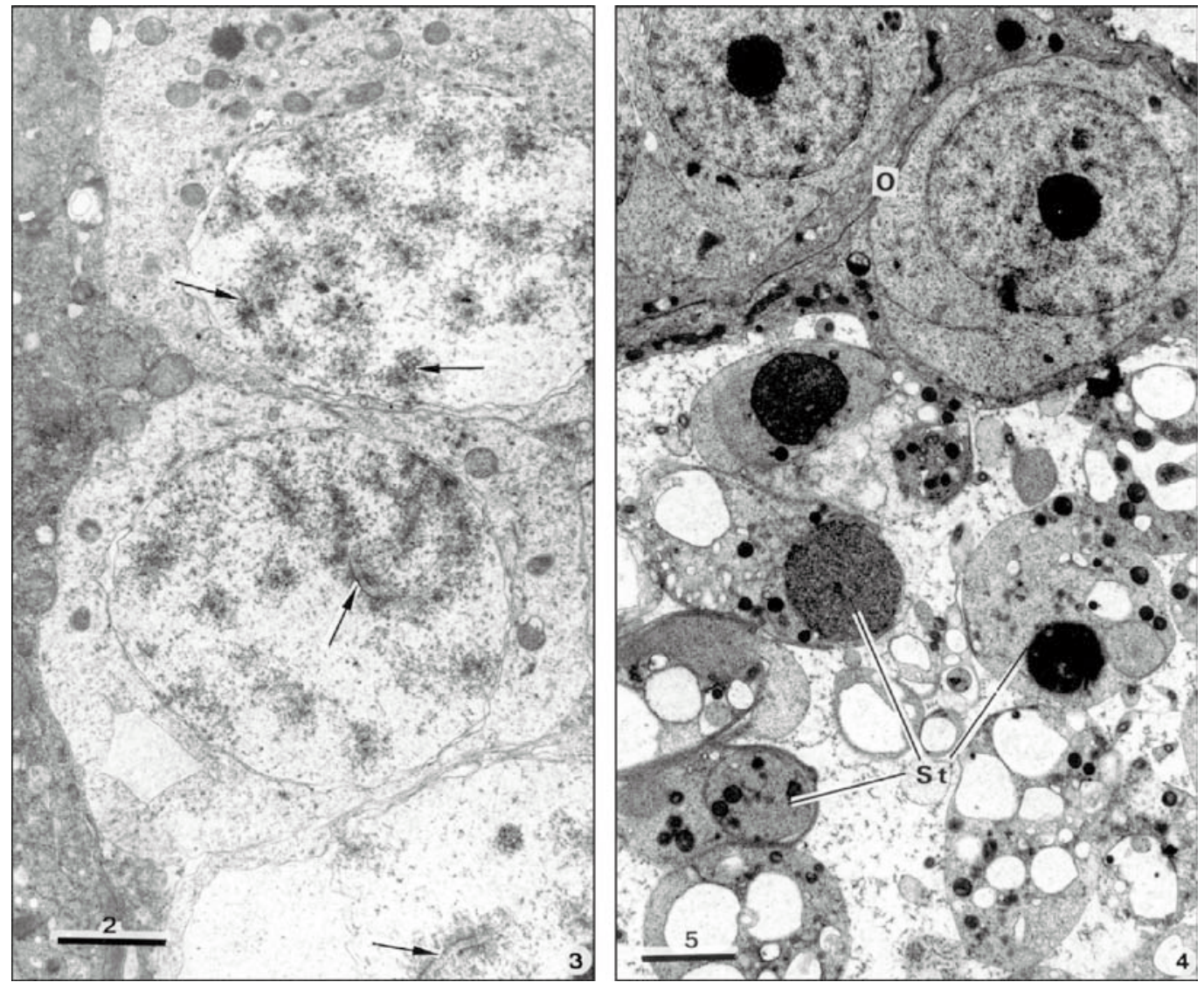

Fig. 3 - Ultrathin section of spermatocytes showing the synaptonemal complexs (arrows). Fig. 4 - Ultrathin section of two oocytes $(\mathrm{O})$, each containing a prominent nucleolus, near of young spermatids $(\mathrm{St})$. 

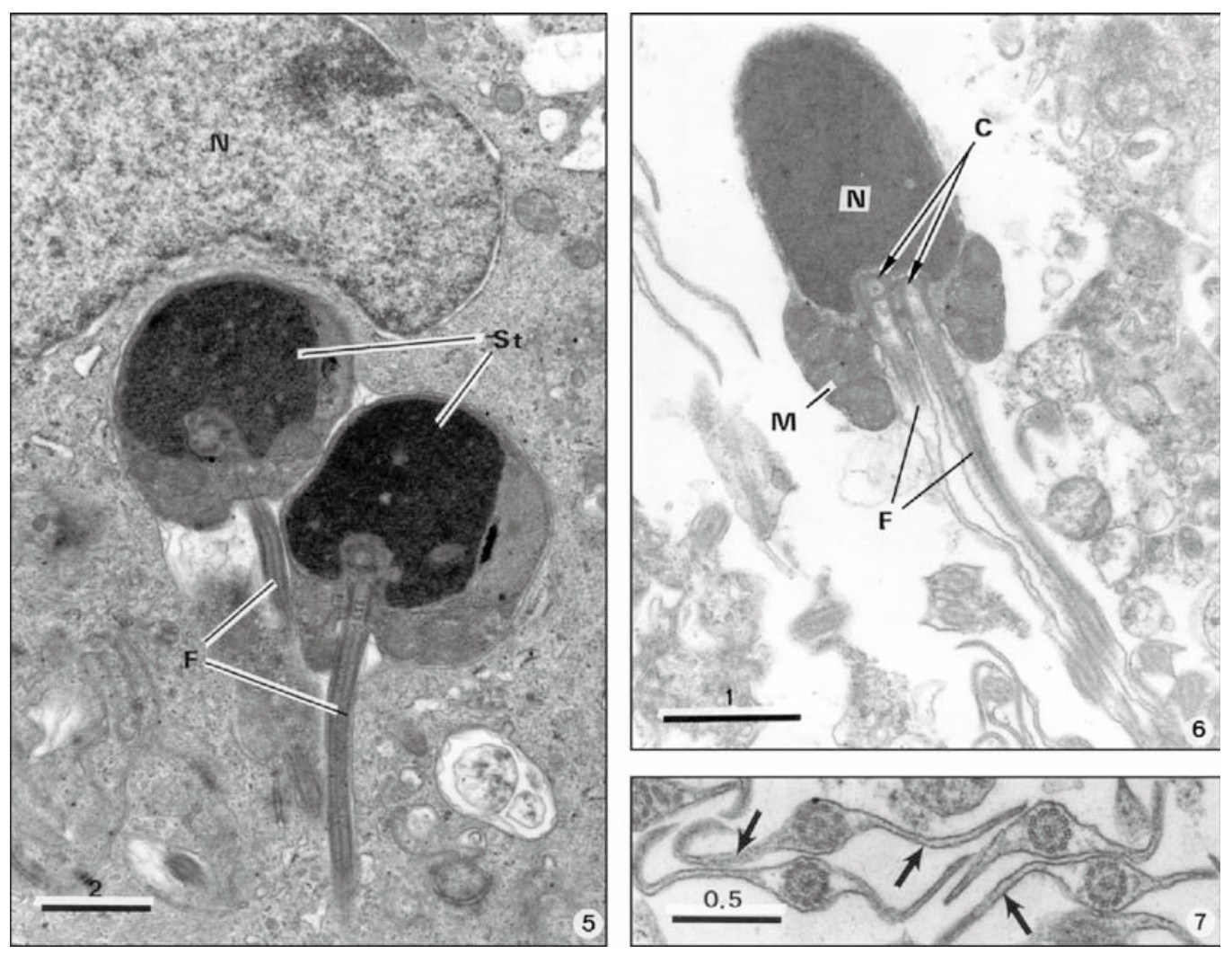

Fig. 5 - Ultrathin section showing a Sertoli cell with a large nucleus (N) containing two middle spermatids (St), each showing one of the two flagella (F). Fig. 6 - Ultrathin longitudinal section of a spermatozoon showing a dense nucleus (N) without acrosome, two centrioles (C) each one in continuity with two flagela (F) the mitochondrial collar (M) forming the midpiece surrounded the basal portion of the nucleus centriolar region and the begin of the flagella. Fig. 7 - Ultrathin transverse section of four flagella showing a pair of lateral ribbons (arrows) and the axoneme composed of the classic $9+2$ microtubular patterns in each.

They extend along most of the length of the tail. The largest extensions, including the axoneme has $3 \mu \mathrm{m}$ in diameter (Fig. 7). The axoneme exhibits a common $9+2$ microtubular pattern (Figs. 7 and 9) along of the tail length.

\section{DISCUSSION}

The morphological structure exhibited by sperms of the teleost Satanoperca jurupari described here show similarity to those described in most of the teleostean species in which the absence of acrosome is a common character (Mattei, 1970). Although they belong to the primitive type they show some unusual features. To date all the fish spermatozoa examined show some structural homogeneity which supports the idea that the ultrastructural features of spermatozoon can be useful for taxonomic and phylogenetic studies (Baccetti et al., 1984; Mattei, 1991; Mattei \& Mattei, 1984; Gwo et al., 1993, 1996).

Biflagellate spermatozoa of teleost have been described in few species. Most of the teleost groups possess uniflagellate tails that contain the $9+2$ microtubular patterns. However, a few teleost species have a biflagellate spermatozoon species (Mattei \& Mattei, 1984) similar to those described in this work. On the other hand, in most of the different teleost species, the tail does not exibiht any plasmatic ornamentation, characterized by lateral ribbons on cytoplasmic extension along the axoneme. 

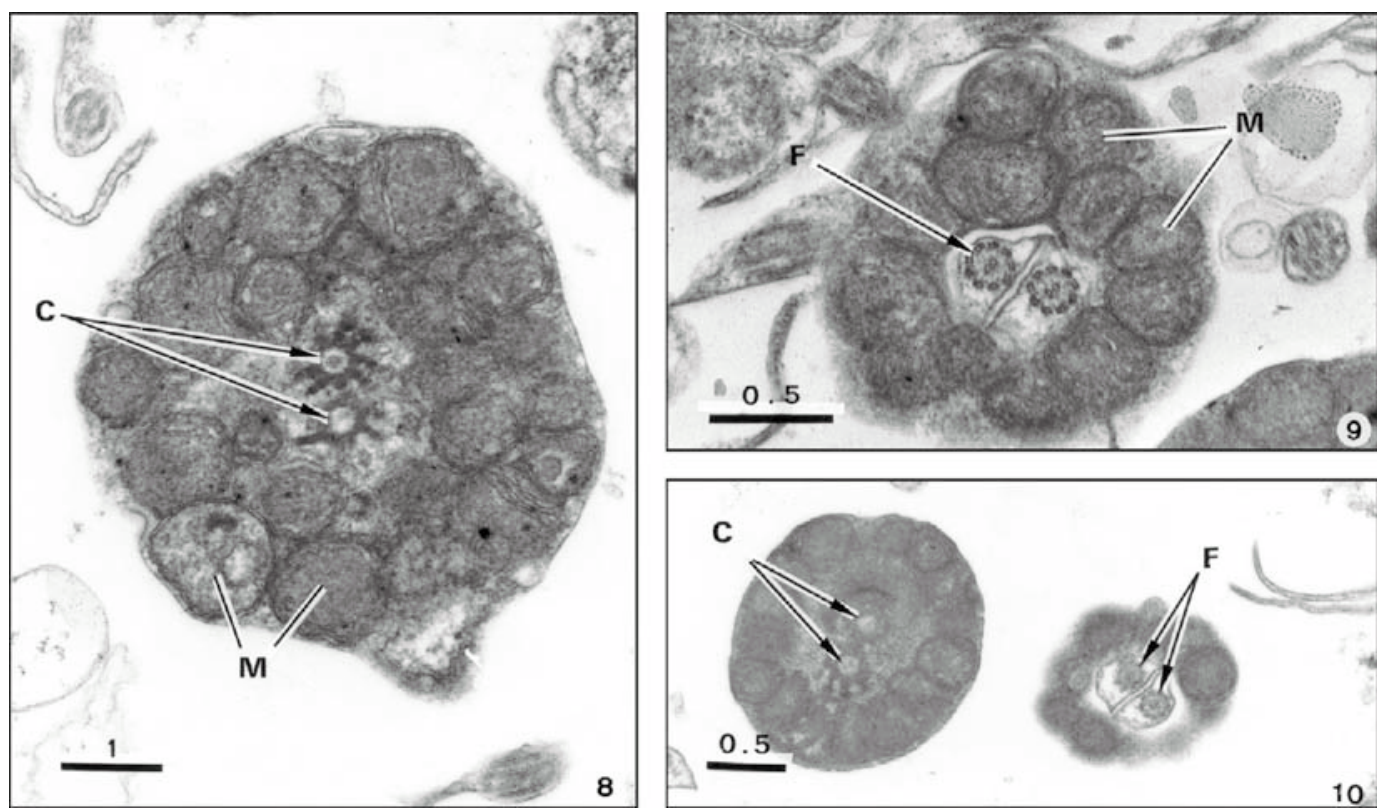

Figs. 8-10 - Ultrathin transverse sections of three sequential portions of the midpiece showing the centrioles (C) surrounded by mitochondria $(\mathrm{M})$ of the mitochondrial collar and the two flagella $(\mathrm{F})$.

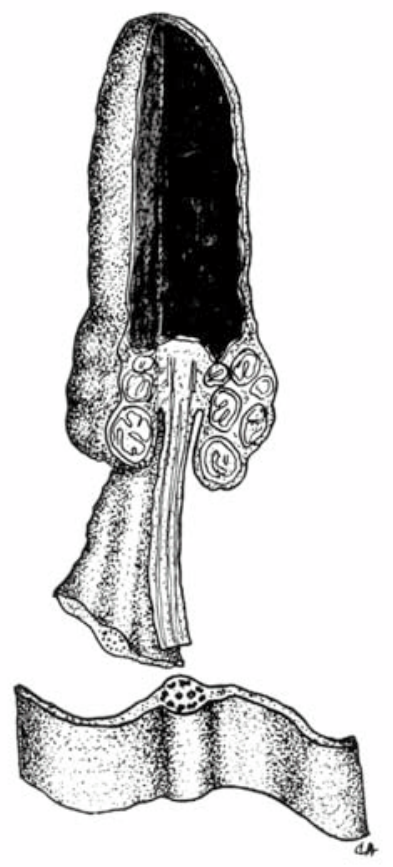

Fig. 11 - Schematic drawing of the mature spermatozoon of Satanoperca jurupari. 
A similar nature has been described in teleost species of the Batrachoididae family (Hoffman, 1963; Stanley, 1965). These structures seem to have a great importance in stabilization and motility (Stoss, 1983). In some other fishes as in Dipnoi, genera Protopterus and Polypterus (Mattei, 1970), and Lepidosiren paradoxa (Matos \& Azevedo, 1989) the biflagellate spermatozoa are also present as cytoplasm extensions.

Although spermazoan structure has been reported from about 300 fish species spread over more than 100 families (Mattei, 1991; Jamieson, 1991), $S$. jurupari is the first member of the family Cichlidae from Brazil to be examined. Examination of other cichlids will be necessary to determine whether the primitive features of $S$. jurupari spermatozoa are common to this family (Mattei, 1991).

This investigations will also furnish the information needed for determining the phylogenetic position to the Cichlids on the basis of spermatozoan structure which is known to be a valuable indicator of phylogenetic relationships in numerous groups (Mattei, 1991; Jamieson, 1991; Gwo et al., 1993).

Acknowledgments - We thank the excelent technical assistence of Mrs Laura Corral and the ichonographic work of Mr J. Carvalheiro. This work was partially supported by A. Almeida Foundation, Porto, Portugal and FCAP-Belém, Pará, Brazil.

\section{REFERENCES}

BACCETTI, B. \& AFZELIUS, B. A., 1976, In: A. Wolsky (ed.), The biology of the sperm cell. Basel, S., Karger, pp. 1-254.

BACCETTI, B., BURRINI, A. G., CALLAINI, G., GIBERTINI, G., MAZZINI, M. \& ZERUNIAN, S., 1984, Fish germinal cells. I. Comparative spermatology of seven cyprinid species. Gamete Res., 10: 373-396.

BILLARD, R., 1970, Ultrastructure comparée de spermatozoide de quelques poissons téléostéens, pp. 71-79. In: B. Baccetti (ed.), Comparative spermatology. Academic Press, New York.

GWO, J. C., GWO, H. H. \& CHANG, S. L., 1993, Ultrastructure of the spermatozoon of the teleost fish Acanthopagrus schlegeli (Perciformes; Spanidae). J. Morphol., 216: 29-33.
GWO, J. C., LIN, X. W., GWO, H. H., WU, H. C. \& LIN, P. W., 1996, The ultrastructure of Formosan landlocked salmon, Oncorbynchus masou formosanus, spermatozoon (Teleostei; Salmoniformes, Salmonidae). J. Submicrosc. Cytol. Pathol., 28: 33-40.

HOFFMAN, R. A., 1963, Gonads, spermatic ducts, and spermatogenesis in the reproductive system of male toadfish, Opsanus tau. Chesapeake Sc., 4: 21-29.

JAMIESON, B. G. M., 1991, Fish evolution and systematics: evidence from spermatozoa. Cambridge University Press, New York, pp. 319-320.

MATOS, E. \& AZEVEDO, C., 1989, Ultrastructural study of the spermatogenesis of Lepidosiren paradoxa (Pisces, Dipnoi) in Amazon region. Rev. Bras. Ciên. Morfo, 6: 67-71.

MATTEI, C. \& MATTEI, X., 1984, Spermatozoides biflagellés chez un poisson téléostéen de la famille des Apogonides. J. Ultrastruct. Re., 88: 223-228.

MATTEI, X., 1970, Spermiogenèse comparée des Poissons. pp. 57-69. In: B. Baccetti (ed.), Comparative spermatology. Academic Press, New York.

MATTEI, X., 1991, Spermatozoon ultrastructure and its systematic implications in fishes. Can. J. Zool., 69: 30383055 .

MATTEI, X. \& MATTEI, C., 1976, Spermatozoides à deux flagelles de type $9+0$ chez Lampanyctus sp. (Poisson Myctophidae). J. Microscopie Biol. Cell., 25: 187-188.

ROUSE, G. W. \& JAMIESON, B. G. U., 1987, An ultrastructural study of the spermatozoa of the polychaetes Eurythoe complanata (Amphinomidae), Clymenella sp. and Micromaldane sp. (Maldanidae), with definition of sperm types in relation to reproductive biology. J. Submicrosc. Cytol., 19: 573-584.

STANLEY, H. P., 1965, Electron microscopic observations on the biflagellate spermatids the teleost fish Porichtys notatus. Anat. Rec., 151: 477.

STOSS, J., 1983, Fish gamete preservation and spermatozoon physiology, pp. 305-350. In: W. S. Hoar, D. J. Randall \& E. M. Donaldson (eds.), Fish physiology. v. 9, Academic Press, New York.

YAO, Z., EMERSON, C. J. \& CRIM, L. W., 1995 Ultrastructure of the spermatozoa and eggs of the ocean Pout (Macrozoarces americanus L.), an internally fertilizing marine fish. Molecular Reproduction and Develop., 42: 58-64.

YASUZUMY, F., 1971, Electron microscope study of the fish spermiogenesis. J. Nara Med. Ass., 22: 343-355. 